\title{
A personagem de ficção e a reportagem
}

\author{
The character of fiction and the report \\ Mei Hua Soares \\ Faculdade Cásper Líbero - São Paulo - Brasil
} $\diamond$

Resumo: Parte de uma pesquisa que investiga os entrecruzamentos entre Literatura e Comunicação e seus desdobramentos, o artigo aborda questões referentes à presença de elementos literários, em especial características próprias de personagens de ficção, em gêneros jornalísticos como a reportagem investigativa. Para tanto, o presente estudo analisará a reportagem "Os trabalhos e os dias", da jornalista Natália Viana, publicada na Revista Caros Amigos (2005). A fundamentação teórica se estruturará a partir de concepções do filósofo francês Jean-Paul Sartre (relacionadas à subjetividade, totalização, densidade obscura e singularização do universal) e se apoiará em categorizações sobre o mecanismo de criação propostas pelo sociólogo e teórico literário Antonio Candido.

Palavras-chave: Literatura; Comunicação; Jornalismo; Personagem de ficção; Reportagem

Abstract: Part of a research that investigates the interrelationships between Literature and Communication and its unfolding, the article addresses questions related to the presence of literary elements, especially characteristics of fictional characters, in journalistic genres such as investigative reporting. For this, the present study will analyze the report "The works and the days", of the journalist Natália Viana, published in the magazine Caros Amigos (2005). The theoretical foundation will be structured from the conceptions of the French philosopher Jean-Paul Sartre (related to subjectivity, totalization, obscure density and singularization of the universal) and will be based on categorizations on the creation mechanism proposed by sociologist and literary theorist Antonio Candido.

Keywords: Literature; Communication; Journalism; Fictional character; Reportage

O Homo fictus é e não é equivalente ao Homo sapiens, pois vive segundo as mesmas linhas de ação e sensibilidade, mas numa proporção diferente e conforme avaliação também diferente. (...) Do ponto de vista do leitor, a importância está na possibilidade de ser ele conhecido muito mais cabalmente, pois enquanto só conhecemos o nosso próximo do exterior, o romancista nos leva para dentro do personagem.

ANTONIO CANDIDO

Aliás, é preciso que o personagem, como D. Quixote, por exemplo, seja um personagem cheio de manias, uma espécie de imbecilidade que, no início, espanta: ele se comporta primeiro como um ser original, um personagem entre mil. E depois é preciso que, sem ele deixar de ser esse tipo original, seja possível sentir nele todas as contradições de uma época. Então, você tem o fato que é constante, o fato real e individual da vida de cada um: que somos encarnações, isto é, somos a singularização de todo o universal dos sistemas nos quais vivemos. 
Influenciado pela leitura de novelas de cavalaria, o fidalgo D. Quixote - ou Cavaleiro da Triste Figura -, emblemático personagem da literatura universal, sai pelo mundo para desbravá-lo (tendo a seu lado o fiel Sancho Pança) em busca de aventuras e situações que reforcem a sua condição de cavaleiro defensor de donzelas em perigo, de oprimidos e injustiçados. A narrativa de ficção criada por Miguel de Cervantes, cuja primeira parte foi editada em 1605, trata do estigma da coragem e da ilusão humanas em direção às utopias, àquilo que move e motiva o homem.

Se as leituras impulsionam, de modo inclusive equivocado e cômico, a personagem de ficção na trama, que influência teriam na vida real e na formação humana? A leitura esteve e está presente nos percursos de vida. Apesar da imprecisão de seu alcance enquanto elemento formativo nos processos de aprendizagem e constituição do sujeito, talvez seja possível mensurá-la a partir de nossas próprias experiências de leitura. A leitura utilitária, técnica, pragmática. A leitura de prazer, a de fruição, a que convida para a evasão ou prepara para os embates. $\mathrm{O}$ amplo leque de possibilidades de leitura, de relações e significações que se estabelecem a partir delas, fornecem pistas de seu valor. É perceptível, no entanto, o quanto ainda é complexa a sua introdução e incerta a manutenção de práticas de leitura de literatura, seja na escola básica, seja no ensino superior.

Em diálogos sobre leitura e literatura com alunos e alunas do curso de Comunicação Social (Jornalismo) de uma faculdade paulistana, é recorrente o gosto por leituras mais "palatáveis"1, o que de modo algum deve ser desconsiderado. Best-sellers, romances devoráveis, livros escritos em linguagem acessível têm seu lugar no universo da leitura e devem ser respeitados uma vez que fazem parte e pavimentam os diferentes percursos de leitura que nos constituem. No entanto a leitura de textos mais densos, talvez canônicos, considerados pertencentes a uma suposta esfera literária, também têm vez e lugar. Certamente esse assunto repousa em terreno bastante

\footnotetext{
1 A respeito do controverso assunto, o ensaísta e editor Alberto Manguel salienta: "Boa parte do público leitor é treinado a esperar certa espécie de livro 'confortável' e, pior ainda, a lê-lo de um certo modo 'confortável', voltado para as descrições curtas, padrões de diálogo copiados das sitcoms televisivas. Nomes de marcas conhecidas e tramas que, por mais que se emaranhem, não são nunca ambíguas ou complexas. O filósofo alemão Axel Honneth, valendo-se de um termo cunhado por Georg Lukács, chama esse processo de reificação. Por reificação, Lukács referia-se à colonização do mundo da experiência por generalizações unidimensionais provenientes das regras da troca comercial: a reificação não cria valores e identidades por meio de histórias imaginativas, mas meramente segundo o que se diz que uma coisa custa e o que se está disposto a pagar por ela" (MANGUEL, 2008, p. 118). Já Antonio Candido, em "O direito à Literatura", defende um conceito de Literatura mais abrangente: "Chamarei de Literatura, da maneira mais ampla possível, todas as criações de toque poético, ficcional ou dramático em todos os níveis de uma sociedade, em todos os tipos de cultura, desde o que chamamos folclore, lenda, chiste, até as formas mais complexas e difíceis de produção escrita das grandes civilizações" (CANDIDO, 2013, p. 176).
}

arenoso, uma vez que a definição de literatura, o que é passível de ser considerado literário ou não literário está longe de ser uma questão simples. O que se pretende investigar é de que maneira a literatura pode formar e se tornar referência na área de comunicação e jornalismo gerando interfaces válidas.

Em pesquisa voltada à investigação dos percursos de leitura literária, trilhados por docentes de Comunicação Social $^{2}$, estudos revelaram a dimensão formativa envolvida na leitura de literatura, em diálogo com as áreas específicas de Comunicação e acabaram por revelar outras facetas interessantes provenientes do diálogo entre Literatura e Comunicação Social: a presença direta ou indireta de características estruturantes próprias da personagem de ficção e de elementos literários nos gêneros textuais jornalísticos. Partindo do pressuposto de que a literatura pode consistir em importante aliada na formação de comunicadores, o assunto (explorado em estudos e disciplinas que tratam do jornalismo literário) será abordado considerando os conceitos filosóficos de subjetividade, totalização, densidade obscura e singularização do universal disseminados por Jean-Paul Sartre e da análise de aspectos envolvidos no enredo e na construção de personagens em reportagem da jornalista Natália Viana, "Os trabalhos e os dias".

Antonio Candido, em artigo escrito a partir de explanação proferida em 1972, "A literatura e a formação do homem", enumera aporias a respeito da transformação da literatura em ferramenta de educação moral enfatizando o seu caráter independente e afirmando que a literatura "para além do bem e do mal, educa porque faz viver" (CANDIDO, 1972, p. 85). Portanto, segundo Candido, a literatura não estaria a serviço de algo. Entretanto, atenderia à necessidade de ficção e de fantasia que o mesmo autor defende ser latente em todo ser humano. Também em $A$ personagem de ficção, Candido afirma que:

\begin{abstract}
Na vida cotidiana ou na leitura de textos não estéticos, a nossa intenção geralmente atravessa a superfície sensível devido à imposição de valores práticos, vitais, teóricos etc. $\mathrm{O}$ raio de intenção (...) dirige-se diretamente ao que "interessa", por exemplo, às atitudes e palavras (...). A experiência estética, bem ao contrário, é "desinteressada", isto é, o objeto já não é meio para outros fins, nada nos interessa senão o próprio objeto como tal que, em certa medida, se emancipa do tecido de relações vitais que costumam solicitar a nossa vontade. É o "fenômeno da moldura" que, nas várias artes de modo diverso, isola o objeto estético, como área lúdica, de situações reais (às quais, contudo, pode referir-se indiretamente) (CANDIDO, 2014, p.40).
\end{abstract}

\footnotetext{
2 O projeto A leitura literária e a formação em Comunicação faz parte das pesquisas realizadas e subsidiadas pelo Centro de Pesquisa Interdisciplinar (CIP) da Faculdade Cásper Líbero.
} 
Voltando nosso olhar (sem deixar de lado a perspectiva salientada por Candido) para o gênero reportagem - um gênero jornalístico, portanto informativo, referencial, factual e, em tese, comprometido com a ideia de verdade -, que efeitos e funções essa intersecção entre estruturas literárias de ficção e linguagem referencial adquirem em reportagens?

A literatura pode, direta ou indiretamente, colaborar com a aquisição, por parte do comunicador, de possibilidades criativas e efeitos de linguagem alcançados pelo uso de recursos literários. Mas que efeitos poéticos, estéticos ou literários podem ser tornados familiares a ponto de serem incorporados em suas próprias produções escritas, imagéticas, sonoras? Metáforas, gradações, metonímias, eufemismos, variações linguísticas e estilísticas de linguagem, diversidade lexical, traquejo no uso de tipologias textuais variadas (narração, descrição, argumentação, injunção) e na mescla de diferentes gêneros discursivos são sintomáticos de quem lê e produz textos literários. Certamente existem exceções, mas, em geral, é comum que a leitura de bons textos (de textos significativos) resulte em parâmetro para a escrita impulsionando a produção textual. E como se dão essas supostas incorporações estratégicas na produção dos textos jornalísticos?

Umberto Eco, ao discorrer sobre as especificidades e encaminhamentos da literatura, menciona o impacto das personagens de ficção apontando para o fato de que, apesar de não ser prioridade na vida dos sujeitos em geral, sem a literatura o mundo seria bem menos humano ${ }^{3}$. Candido também defende a tese de que a literatura (lado a lado com as demais artes) deve ser considerada um bem incompressivel ${ }^{4}$, ou seja, indispensável à vida, uma vez que, segundo ele, todos necessitamos de doses de fantasia e de ficção para sobreviver e para nos reconhecermos enquanto seres humanos (CANDIDO, 1972). Além disso, Candido toca em questão fulcral ao alçar a literatura ao patamar dos bens inalienáveis, pois põe em evidência o fato de que considerar a literatura e as demais artes supérfluas às camadas mais pobres, faz com que seja reafirmada a sua permanente

\footnotetext{
3 “ (...) nem eu seria idealista a ponto de pensar que às imensas multidões às quais faltam pão e remédios, a literatura poderia trazer alívio. Mas uma observação eu gostaria de fazer: aqueles desgraçados que, reunidos em bandos sem objetivos, matam jogando pedras dos viadutos ou ateando fogo a uma menina, sejam eles quem forem afinal, não se transformaram no que são pelo newspeak do computador (...), mas porque restam excluídos do universo do livro e dos lugares onde, através da educação e da discussão, poderiam chegar até eles os ecos de um mundo de valores que chega e remete a livros" (ECO, 2003, p. 12).

4 "Certos bens são obviamente incompressíveis, como o alimento, a casa, a roupa. Outros são compressíveis, como os cosméticos, os enfeites, as roupas supérfluas. Mas a fronteira entre ambos é muitas vezes difícil de fixar, mesmo quando pensamos nos que são considerados indispensáveis" (CANDIDO, 2013, p. 175).
}

exclusão ${ }^{5}$ da cultura letrada e dos campos simbólicos de poder. Nesse sentido, poderíamos pensar de que maneira a literatura poderia ser tornada popular e acessível, inclusive por intermédio de textos que circulam com maior incidência junto aos grandes contingentes populacionais (como as crônicas, os artigos, as reportagens e os perfis, por exemplo).

Já Tzvetan Todorov, o historiador e ensaísta búlgaro, ressalta a literatura como fator de humanização. De acordo com o autor, a literatura opera transformações a partir de modificações sensíveis no leitor. Além disso, assim como Eco, enfatiza o caráter didático que a literatura pode envolver ${ }^{6}$ :

\begin{abstract}
A literatura pode muito. Ela pode nos estender a mão quando estamos profundamente deprimidos, nos tornar ainda mais próximos dos outros seres humanos que nos cercam, nos fazer compreender melhor o mundo e nos ajudar a viver. Não que ela seja, antes de tudo, uma técnica de cuidados para com a alma; porém, revelação do mundo, ela pode também, em seu percurso, nos transformar a cada um de nós a partir de dentro (TODOROV, 2012, p. 76).
\end{abstract}

Nosso intuito, numa perspectiva mais ampla, é também entender se a leitura e o contato efetivo com textos literários constituem possível ferramenta pedagógica formativa ou se contribui para que as dimensões estética, estilística e poética (em diálogo com a dimensão política, social e cultural) sejam contempladas na formação do sujeito influenciando também a sua escrita.

\section{Madame Bovary e a retotalização sartreana}

Convidado por membros do Instituto Gramsci (Roma), Jean Paul-Sartre participou de caloroso debate com os principais intelectuais e dirigentes da esquerda italiana, em 1961. Sartre buscava responder à pergunta que o perseguia desde 1930: "O que é a subjetividade?" Já os italianos do instituto buscavam colocar no centro da roda o problema da subjetividade no âmbito da filosofia marxista. O que decorre desses profícuos diálogos são conceitos que podem iluminar questões relacionadas à feitura e ao movimento que estrutura as obras de arte,

\footnotetext{
"O fato é que cada época e cada cultura fixam os critérios de incompressibilidade, que estão ligados à divisão da sociedade em classes, pois inclusive a educação pode ser instrumento para convencer as pessoas de que o que é indispensável para uma camada social, não o é para outra" (CANDIDO, 2013, p. 175).

6 "A realidade que a literatura aspira compreender é, simplesmente (mas, ao mesmo tempo, nada é assim tão complexo), a experiência humana Nesse sentido, podemos dizer que Dante ou Cervantes nos ensinam tanto sobre a condição humana quanto os maiores sociólogos e psicólogos e que não há incompatibilidade entre o primeiro saber e o segundo" (TODOROV, 2012, p. 77).
} 
mais especificamente as literárias, o que nos importa abordar aqui.

De acordo com o pensamento sartreano, o "não saber" seria a consciência como consciência de si não reflexiva (como fruto de uma não reflexão) e envolveria intermitências entre momentos de reflexão e de uma "consciência inconsciente". "O ter de ser", segundo o filósofo, é o modo de ser da consciência, que é assim um existente: "Eis uma primeira característica essencial da subjetividade: se a subjetividade é, por definição, não saber, mesmo no nível da consciência, é porque o indivíduo, ou o organismo, tem de ser o seu ser" (SARTRE, 2015, p. 15). Sartre aponta duas possibilidades: a existência material, como no caso limite do sistema material puro, e outra, buscando modificar o conjunto a fim de assegurar sua manutenção, como no caso da práxis. Entre as duas, há a condição de interioridade no sentido em que o todo não é algo dado que se trataria de preservar quando ameaçado, mas algo que convém sempre preservar, porque nunca é dado definitivamente (KAIL e KIRCHMAYR apud SARTRE, 2015, p. 15-16):

O todo é, na realidade, uma lei de interiorização e de reorganização perpétua; equivale a dizer que o organismo é mais uma totalização do que propriamente um todo; o todo só pode ser uma espécie de autorregulação que causa perpetuamente essa interiorização. A totalização se dá pela intervenção do exterior que perturba, que muda (SARTRE, 2015, p. 16).

Sartre afirma ainda que a subjetividade consiste em movimento contínuo e dialético de interiorização e retotalização que gera dois tipos de totalização: a de envolvimento (de dentro do indivíduo para o externo) e a de condensação (do externo, do social, para dentro) ${ }^{7}$, o que promoveria a representatividade ficcional, por exemplo.

O filósofo, para exemplificar sua concepção de subjetividade, toma como exemplo o autor Gustave Flaubert e sua obra mais conhecida, Madame Bovary. Avançando na análise da elaboração das obras estéticas, Sartre enfatiza a presença de uma "densidade obscura" na arte e no artista salientando a sua relação dialética presente na obra de arte:

\footnotetext{
“(...) a subjetividade é interiorização e retotalização, isto é, no fundo, para retomar termos mais vagos e, ao mesmo tempo, mais conhecidos: vive-se; a subjetividade é viver o seu ser, vive-se o que se é, e o que se é em uma sociedade, pois não conhecemos outro estado do homem ele é precisamente um ser social, ser social que, ao mesmo tempo, vive a sociedade inteira do seu ponto de vista. (...) Aliás, é apenas porque podemos conceber o jogo dialético de uma totalização de envolvimento, isto é, de uma totalização que se estende ao conjunto social, e de uma totalização de condensação, o que chamo de encarnação, que faz com que cada indivíduo seja, de certo modo, a representação total de sua época" (SARTRE, 2015, p.99-100).
}

(...) mesmo se for conhecida como objeto [a obra de arte], vamos reencontrá-la sob uma forma não conhecida, ignorada, e na medida em que o artista projeta, ele não se conhece, mesmo que, em outro plano, ele se conheça muito bem. Quando Flaubert escreve, ele pensa em Madame Bovary; quando lhe atribui certas reações, ele pensa que são as mesmas que essa mulher teria, e depois, ao refletir sobre o que acabou de escrever, ele se diz que teria tido as mesmas, que lhe atribuiu suas próprias reações. Por isso, encontramos o jogo que evocávamos, e acho que é impossível imaginar a arte a não ser como ponto de encontro entre o objetivo e o subjetivo (SARTRE, 2015, p. 104-105).

Outro ponto fundamental em Sartre é quando ele realiza distinções entre o ponto de vista do historiador e o do autor literário nas narrativas e romances históricos. A personagem sofrerá implicações, dependendo da abordagem a que se pretende, e, ao que parece, segundo a ótica sartreana, a personagem literária fictícia se revelaria multifacetada, portanto mais rica, porque vista sob diferentes ângulos ${ }^{8}$. O filósofo também lança mão da obra D. Quixote, de Miguel de Cervantes, para ressaltar o caráter mais fechado das narrativas e discursos essencialmente históricos e da complexidade das narrativas literárias ${ }^{9}$

\footnotetext{
"Prestem atenção, quando escrevo um romance histórico, meu objetivo é diferente. Porque quando faço uma descrição, o personagem histórico não é aquele visado pelo historiador. O historiador considera o personagem em sua significação histórica, mas eu o vejo em todos os enredos de sua vida real, como os outros homens'. Em relação a esse processo de 'desnaturalização' do protótipo realista, será possível fazer a pergunta à qual volto, pela qual vou concluir e não me sinto apto a responder. Parece-me que é a pergunta fundamental: a que gênero de conhecimento pertence a arte e em que ela difere dos outros gêneros de conhecimento?" (SARTRE, 2015, p. 113-114).

9 “(...) é precisamente porque a arte é um discurso fechado, no sentido em que o senhor projetou a sociedade singularizada sobre uma totalidade, que é a descrição dessa mesma sociedade. Ou seja, nunca pedimos a uma obra de arte informações objetivas a respeito de um período. Pedimos-lhe um tipo de informações mais complexas, que também não são informações objetivas, mas é a sua repetição de um período vendo a si mesmo com todas as suas cegueiras possíveis, com todos os seus preconceitos, mas, ao mesmo tempo, ele se vê, não é? Ela representa uma totalização do período sob a forma do indivíduo ou do grupo de indivíduos que a fez. Tomemos, por exemplo, D. Quixote: o que leva D. Quixote a permanecer? Há um aspecto histórico que poderia interessar apenas aos historiadores: é a liquidação de certa sociedade feudal. Na época em que as monarquias absolutas vão se constituir e, por conseguinte, no mesmo momento do Renascimento, assiste-se também à liquidação dessa feudalidade, a liquidação de uma ideologia feudal em proveito de outra ideologia, em um homem que vive essa contradição. A liquidação dessa feudalidade sob a forma dos romances de cavalaria, em um homem que vai agora ser simplesmente soldado do rei e não um cavaleiro errante, é uma coisa que interessa do ponto de vista estritamente histórico, se assim o considerarmos. Mas se lemos isso em um livro em que esse homem projetou tais contradições, damos com um personagem como D. Quixote, quase sempre ridículo e de vez em quando trágico, não é? Com essa estranha espécie de contradição que é a do próprio Cervantes. Nesse momento temos algo que nos interessa porque oferece toda essa sociedade como uma sociedade tão viva de contradições como aquela em que vivemos. (...) a subjetividade de Cervantes é indispensável para tornar a obra de D. Quixote ligada a nós e, precisamente, na medida em que Cervantes estava muito mal, muito mal consigo mesmo, pois assistia a essa separação dos dois mundos" (SARTRE, 2015, p. 128-129).
} 
justamente pelo fato de serem capazes de trazer à tona as subjetividades que acabam por delinear o que ele chama de "singularização do universal":

(...) não acho que um personagem histórico seja típico. Não crio que a ‘tipologização' seja de fato o objetivo pelo menos um personagem romanesco típico -, seja o objetivo do romance. Acho que é mais a singularização do universal, o que não quer dizer típico. Mas, na realidade, acho que é preciso representar personagens que tenham inicialmente certo grau de obscuridade, que é a sua individualidade, a sua personalidade, e nos quais pouco a pouco o leitor, sem nunca passar ao universal em si, consegue encontrar no concreto essa universalidade. (...) Aliás, é preciso que o personagem, como D. Quixote, por exemplo, seja um personagem cheio de manias, uma espécie de imbecilidade que, no início, espanta: ele se comporta primeiro como um ser original, um personagem entre mil. E depois é preciso que, sem ele deixar de ser esse tipo original, seja possível sentir nele todas as contradições de uma época. Então, você tem o fato que é constante, o fato real e individual da vida de cada um: que somos encarnações, isto é, somos a singularização de todo o universal dos sistemas nos quais vivemos (SARTRE, 2015, p. 129).

Esses dois conceitos - o de "densidade obscura", presente no artista, e o de "singularização do universal", relacionado às personagens fictícias - depreendidos da análise que Sartre faz das obras de arte - ambas fundamentadas no conceito de subjetividade e de (re)totalização - serão utilizados aqui como categorias para se pensar em como se estruturam os personagens que surgem em textos jornalísticos do gênero reportagem. Considerando possíveis hibridismos entre literatura e jornalismo, bem como a apropriação de recursos da área literária por parte de muitos repórteres e jornalistas, gostaríamos de verificar em que medida a absorção de elementos próprios da área literária, no que diz respeito à construção de personagens, pode ocasionar efeitos interessantes e impactantes.

\section{Personagem reproduzida, personagem inventada}

Antonio Candido, em A personagem de ficção, afirma que uma das funções capitais da ficção é a de fornecer um conhecimento mais abrangente, profundo e complexo dos seres. $\mathrm{O}$ autor ressalta que, na vida real, temos acesso a pouquíssimos fragmentos das pessoas com as quais lidamos cotidianamente (CANDIDO, 2014, p. 62). Para ele, a personagem fictícia é - pela sua construção refletida e sua origem arquitetada - mais lógica do que um ser vivo:
A força das grandes personagens vem do fato de que $o$ sentimento que temos da sua complexidade é máximo; mas isso, devido à unidade, à simplificação estrutural que o romancista lhe deu. Graças aos recursos de caracterização (isto é, os elementos que o romancista utiliza para descrever e definir a personagem, de maneira a que ela possa dar a impressão de vida, configurando-se ante o leitor), graças a tais recursos, o romancista é capaz de dar a impressão de um ser ilimitado, contraditório, infinito na sua riqueza; mas nós apreendemos, sobrevoamos essa riqueza, temos a personagem como um todo coeso ante a nossa imaginação. Portanto, a compreensão que nos vem do romance, sendo estabelecida de uma vez por todas, é muito mais precisa do que a que nos vem da existência. Daí podemos dizer que a personagem é mais lógica, embora não mais simples, do que o ser vivo (CANDIDO, 2014, p. 59).

Apoiando-se em outros autores, Candido distingue as personagens fictícias em "personagens de costumes" (correspondentes ao que Forster nomeou de "personagens planas", chapadas, simplificadas) e as "personagens de natureza" ou "personagens esféricas" (temperamentais, que surpreendem o leitor, multifacetadas). Além disso, Candido recupera uma classificação de personagens proposta por Mauriac ${ }^{10}$, que consiste em diferenciálas quanto ao grau de proximidade com a realidade (cópia, reprodução, invenção), e avança aprimorando a esquematização que apresenta diferentes matizes da criação de personagens existentes entre os dois polos opostos, o da transposição ideal de modelos oriundos da "vida real" e o da invenção totalmente imaginária: 1) personagens transpostas com relativa fidelidade a partir de modelos provenientes de experiências diretas do romancista (seja interior ou exterior); 2) personagens transpostas de modelos anteriores que o romancista reconstitui indiretamente (por documentação, por testemunho); 3) personagens construídas a partir de um modelo real que serve de ponto de partida; 4) personagens construídas a partir de um modelo conhecido, mas que é apenas um pretexto que estimula o trabalho de caracterização; 5) personagens construídas em torno de um modelo real ao qual vêm se juntar outros modelos secundários; 6) personagens elaboradas com fragmentos de vários modelos vivos, resultando uma personalidade nova; 7) personagens cujas raízes desaparecem de tal modo na personalidade fictícia determinante que não podem ser traçados pelo próprio autor (CANDIDO, 2014, p. 72-73).

\footnotetext{
${ }^{10}$ Mauriac realiza a seguinte diferenciação: 1) personagem-disfarceleve de romancista (em geral memorialistas); 2) cópia fiel de pessoas reais, reproduções (comuns em romancistas retratistas); 3 ) personagens inventadas a partir de um estímulo inicial proveniente da realidade (CANDIDO, 2014, p. 68).
} 
Candido traz esses importantes apontamentos referindo-se à personagem fictícia no romance. Mantendo essa categorização em nosso horizonte, gostaríamos de verificar em que medida ela poderia nos ajudar a pensar na personagem que existe, é proveniente da vida real, manteve algum contato com o(a) autor(a) e passa a fazer parte de textos essencialmente factuais, mas que apresentam elementos e aproximações com o campo literário, como é o caso de algumas reportagens jornalísticas. A manipulação dos dados nesse gênero textual permite poucas alterações: grandes saltos inventivos são desaconselháveis. Mas dentro de um limite há certamente lacunas que se não preenchidas com o material imaginário de quem escreve, provavelmente empobreceriam a narrativa. É o que possivelmente acontece com a personagem que adentra as narrativas jornalísticas. Embora existentes na vida real, ao serem transportadas para a esfera textual, em maior ou menor medida, sofrem alterações em virtude das impressões, dos referenciais, das ênfases pretendidas por quem sobre elas escreve. Assim como uma foto jornalística nunca é de fato o real, uma vez que é fruto de ângulos, cortes, edição, tratamento, uma personagem retirada da vida real, por mais preservada que seja ao ser transposta para o texto, sofre seleções, acréscimos, reduções, deduções, impressões etc. Esse entalhe criativo, realizado na personagem já fidedigna por provir da realidade, fica a encargo daquele que escreve. Esse acabamento fictício dado às personagens nas reportagens podem favorecer a fixação de uma lógica perene e, às vezes, de uma coerência que não se sustentaria no plano da "vida real".

\section{"Os trabalhos e os dias", uma reportagem-conto}

A reportagem "Os trabalhos e os dias", de autoria da repórter investigativa Natália Viana, foi publicada em 2005, na Revista Caros Amigos. O texto recebeu menção honrosa, nesse mesmo ano, no Prêmio Vladimir Herzog de Direitos Humanos ${ }^{11}$. Com características notadamente literárias, a reportagem, ao abordar o tema do subemprego e da escravidão moderna, aproxima-se do que Muniz Sodré e Maria Helena Ferrari entendem por reportagem-conto por se amparar na estrutura condutora narrativa e descritiva própria do gênero ${ }^{12}$. A repórter sai a campo - ruas de São Paulo em que há grande concentração de mão de obra desempregada - como se estivesse à procura de trabalho e

\footnotetext{
11 A reportagem na íntegra pode ser lida no site: <https://nataliaviana.org/ reportagens/>.

12 "A típica reportagem-conto tem uma estrutura mais orgânica. Geralmente particulariza a ação em torno de um único personagem, que atua durante toda a narrativa. Os dados documentais entram dissimuladamente na história e o texto aproxima-se tanto do conto, que incorpora até fluxos de consciência dos personagens" (SODRÉ e FERRARI, 1986, p. 81).
}

coleta material de campo que dá sustentação à reportagem. $\mathrm{O}$ que poderia ser abordado de modo estritamente informativo é trabalhado, no entanto, literariamente, como pode ser observado no primeiro parágrafo:

Plim-plim. Vassoura e pano nas mãos, toda terça-feira aparece a Marinete na telinha esfregando um pouco, lavando um pouco, ao som da música-tema que repete "ela é dona do jogo", a personagem principal da rede Globo: uma diarista. Não é coisa pouca, nem tampouco muita coisa, é coisa pra ser notada, embora seu cenário seja limpo demais, geométrico demais, seus "colegas" brancos demais. Daí a ideia, ser faxineira na vida. Ver como é a rotina das mais de 5,3 milhões de pessoas, 93 por cento mulheres, que vivem de organizar, varrer, limpar, esfregar o que outros, sem tempo, com preguiça ou dinheiro demais para se dedicar a fazer, deixam pra trás. Fui procurar trabalho (VIANA, 2005, arquivo eletrônico).

Onomatopeia, jogos de linguagem, inversão, gradação são alguns dos recursos utilizados que capturam a atenção do leitor (o que altamente recomendável no âmbito jornalístico) envolvendo-o logo no início. A presença de elementos próprios das personagens de ficção, a condução marcante da narradora-personagem em primeira pessoa $\mathrm{e}$ o lugar de fala da repórter ${ }^{13}$ (cuidadosamente delimitado) também são aspectos determinantes na estruturação da reportagem.

Outros recursos que costumam vigorar nos gêneros narrativos - diálogos ${ }^{14}$, descrições detalhadas de espaços ${ }^{15}$ e de traços físicos e psicológicos das personagens ${ }^{16}$, enredo perpassado por conflitos maiores e menores ${ }^{17}$

\footnotetext{
13 "Mas domingo tem classificados, e eu coloco um anúncio no Estadão que, mais por fidelidade à verdade do que por exibicionismo, sai meio esdrúxulo: 'Diarista bilíngue com experiência internacional. Preço a combinar. Tel. ...'. Sonho com patroas podres de ricas e gringos solteirões que me chamarão para limpar seus palácios no Morumbi." (VIANA, 2005, arquivo eletrônico, s/p).

14 "Ao som dos berros da patroa:

- Suas lerdas!

Quando termino a primeira dúzia de colares e brincos verdes, já são 10 e meia: 1 real e 50 ganhos. Desisto totalmente de contar o êxito à patroa porque acaba de chegar uma funcionária:

- Sua vaca peituda! Isso é hora?!?! Fazer isso comigo justo hoje, sua vagabunda! Te mato! Já te xinguei tanto aqui! Me deixar na mão assim..." (Idem)

15 "Chego no trabalho, visto avental e touca branca no banheiro dos empregados, um pardieiro: roupas penduradas, o chão lodoso, a privada suja, o armário de ferro entulhado de aventais. Tudo fede a mofo, urina, umidade. (Idem).

16 "Debruçada sobre uma pia pequena e mirando-se no espelho quebrado, encontro uma belíssima Maristela, 30 anos, branca de belos olhos castanhos, que tenta a custo enfiar os cachos negros na touca. Está atrasada e irritada. Contratada há três meses, só pensa em sair dali"; (Idem).

17 "Vou fazendo meus colares, rosa, vermelho, azul, e ouvindo. Naiara, a cabeça cheia de cachaça e vinho San Tomé, fala sem parar: - Mó brisa, mano, tô brisada! Ela conta que a mãe costumava bater a sua cabeça na parede quando ela dedurava ao pai as escapadas noturnas - a mãe se prostituía escondido. Como naquela noite em que entregou a filha a um homem: 'Faz o que ele mandar'. Naiara tinha 8 anos. Na lembrança, ela grita, ri, gesticula nervosamente. Promete que vai matar a mãe. Está 'brisada'”. (Idem).
} 
favorecem o fluxo textual e conferem à reportagem caráter híbrido e trânsito hábil entre as esferas jornalística e literária.

Há trechos que fornecem sustentação e embasamento teórico-informativo, como falas de especialistas sobre o assunto central e seus desdobramentos, estatísticas que confirmam impressões detectadas pela repórter ao longo da narrativa, citações de especialistas ${ }^{18}$. No entanto, esses dados chegam alinhavados à costura narrativa que estrutura a reportagem, o que ocasiona, em diferentes momentos da leitura, efeitos próximos dos alcançados em leituras literárias sem deixar de contemplar o cunho informativo esperado. Aliás, já no título é perceptível a influência da literatura: "Os trabalhos e os dias", ou "As obras e os dias", é o nome do poema épico grego de Hesíodo, cujo mote é o mundo dos mortais e sua organização, o trabalho e a justiça, enfocando a história da civilização durante o período clássico da Grécia Antiga.

A descrição de diferentes personagens da trama conduz a visão do leitor e contribui para que ele passe a perceber que são personagens enredadas pela mesma falha trágica, a da falta de recursos financeiros que as faz vítimas de um ciclo perverso e vexatório, como podemos perceber nesse trecho da reportagem:

As janelas fechadas, tacos soltos no chão, as paredes rabiscadas por lápis de cor, e entramos num quartinho onde seis rostos de meninas me olham, curiosos. É onde vou trabalhar. Elas são negras, mulatas, os cabelos crespos, as mãos rápidas, os rostos jovens. A janela que dá para a rua está coberta por um papelão e a fumaça de muitos cigarros nubla o ambiente. Meu lugar é ao lado de uma negra baixinha e gordinha, a Raquel, "negona" minha companheira de cigarros e de histórias. A patroa - "mulher, baiana e leonina, com orgulho" - está irritadíssima, faltam ainda duzentos colares para fechar uma encomenda pra meio-dia. Quem me ensina o serviço é Shirley, com dois brincos enormes de semente, camiseta justinha, batom, uma princesa de 21 anos. (...) De todas, eu sou a mais velha. Raquel ao meu lado tem 24 anos; na minha frente estão as irmãs Milca, 21, e Bitcha, 17; de costas para a janela fica Naiara, a sobrinha da patroa, de 14 anos; do outro lado, Karen, 22, de touca da Gaviões da Fiel e "sangue nos óio", tem 21. (...) Negona nos

\footnotetext{
18 “Quando contei a saga das 'irmãs bijuteras' para Ricardo Antunes, ele não teve outra palavra senão 'escravidão moderna' para classificar o serviço. Assim: 'É tão brutal a precarização do trabalho em escala global, que o trabalho assalariado volta ao patamar que tinha antes da Revolução Industrial"'; O relatório 'Perfil da Juventude Brasileira', parceria entre o Instituto Cidadania, Instituto de Hospitalidade e Sebrae publicado em abril, quantifica: 52 por cento dos entrevistados ( 3.500 jovens entre $15 \mathrm{e}$ 24 anos de todo o Brasil) temem seu futuro profissional. E vinte por cento acham que o pior de ser jovem é a falta de emprego ou renda, resposta espontânea mais mencionada. $\mathrm{O}$ medo reflete uma realidade: dos que trabalham, 37 por cento não tem registro, 16 por cento vivem de bicos ou empregos temporários. 'Dos desempregados, que são 32 por cento, um terço procura trabalho há mais de um ano"' (Idem).
}

entretém contando como foi "pega pelos homi", quando trabalhava para o "partido". Numa central do PCC, ela, duas meninas e muito pó, enquadradas pelos policiais, teve de desembolsar 7.000 pra se livrar. (...) Quase todas cumpriram o 10 grau, já tiveram outros empregos. Milca foi auxiliar administrativa, Negona era acompanhante de idosos, Vilma trabalhava no Extra. Procurar trabalho, antes de encontrar a "patroa", foi difícil: ninguém queria pagar condução, o que significa um gasto a mais de no mínimo 70 reais por mês. A patroa explora - cada conjunto é vendido a 1 real em pontos na 25 de Março e na Santa Ifigênia, no centro da cidade -, mas pelo menos paga a ida e volta. (Idem).

São diferentes mulheres - Eliana ${ }^{19}$, Denise ${ }^{20}, \mathrm{Néia}^{21}$, Thaís, Tatiane 22 e tantas outras - que vão surgindo da narrativa e são refletidas também na narradora-personagem. Cada uma sua história, suas alegrias e dores

19 "E reflete no rosto de Eliana, uma baixinha morena de belos olhos verdes que conheço numa agência de serviços domésticos. Ela, despedida do serviço de acompanhante de uma idosa porque foi morar com o namorado - a velhinha não gosta disso. Envergonhada, diz que também 'não é tão mau assim': até conseguiu serviço em outra casa, mas saiu sem olhar para trás quando, depois de dias fazendo vezes de faxineira, copeira, cozinheira e arrumadeira - o emprego oferecido era apenas arrumadeira -, foi mordida pelo cachorro, que 'abriu um tanto da minha perna'. A patroa deu risada." (Idem).

20 No bufê espero num balcão quando sai da entrevista uma mulata, cabelo alisado e sorriso satisfeito. No início antipatizo com minha rival, mas depois, ora!, afinal, quem é essa mulher? Ela é Denise, 27 anos, ali pela vaga de passadeira na lavanderia (450 reais), embora metalúrgica por formação. (...) Do último trabalho, na carteira como temporária, foi mandada embora na primeira crise de produção, junto com dezenas de colegas. Agora é se virar, e danem-se mais de sete anos de experiência nas costas. (...) Bem-humorada, ela brinca com o fato de ser considerada velha demais aos 27: 'Agora, nem pra vender eu sirvo mais, eles querem meninas de 18 até 25 anos!'” (Idem).

21 "E a simpática Néia me ensina o próximo serviço, fazer mil-folhados de presunto (na verdade, apresuntado), abrindo o rolo de massa, espalhando o recheio, fechando apertado para não vazar, cortando em cubos e levando ao forno. E repetir, repetir, repetir. O suor escorre pelo rosto, os braços doem e as histórias de Néia me embalam. O filho de 3 anos, cujo pai 'assumiu e sumiu', fica com a mãe enquanto ela trabalha até as 10 horas, às vezes até perde o trem. Filha de baianos, o sotaque nordestino que se confunde com o das outras, já trabalhou na cozinha de um restaurante por quilo, já foi faxineira, fez de tudo um pouco. Mas ficar longe do filho tão pequeno dói. As outras, também, cada uma dá um jeito com os filhos - são cunhadas, avós, tias, parentes, os filhos mais velhos cuidando dos mais novos - e a saudade é unânime naquela cozinha”. (Idem).

22 "Ali, no farol, quem faz a propaganda dos condomínios de luxo é a Thaís, do Capão Redondo, que dorme num cômodo com os sete irmãos mais novos; é a Tatiane, de Paraisópolis, que também divide o quarto com os irmãos, quatro, num andar erguido sobre a laje da casa da mãe. É Tatiane que, sem experiência nem idade pra trabalhar em loja de sapato, cozinha de bufê, fábrica de roupas, tem de levar dinheiro para casa. É Thaís que sonha fazer curso de operadora de telemarketing e está juntando dinheiro para isso. É Tatiane que deita comigo num pedaço escondido e fresco de calçada na hora do almoço. É Thaís que canta comigo Chove Chuva, do Benjor, quando aparecem as primeiras nuvens no céu. Chove torrencialmente, e na cidade centenas de meninas como nós nem se aguentam de felicidade porque podem parar para descansar em algum abrigo. Nós nos escondemos no banheiro do Sam's Club, e é ali que eu descubro que as duas são evangélicas - Tatiane é da Assembleia de Deus e Thaís, da Comunidade Evangélica Pleno - quando gritam, emocionadas, 'aleluia!' para a chuva que lava tudo à nossa volta. Hora depois, o sol volta pra nos acompanhar no resto da tarde. Que demora a passar". (Idem). 
que, embora recontadas brevemente pela repórter, em momento algum são menosprezadas ou desconsideradas em detrimento do teor informativo ou da síntese.

Essas personagens aparentemente secundárias, invisibilizadas socialmente, quando somadas, acabam fornecendo estofo para a configuração uma forte imagem contemporânea arquetípica em chave plural: a da mulher inferiorizada que sofre constantes humilhações em virtude de seu gênero, de sua raça e, principalmente, de sua situação ou condição econômica. À procura de trabalho e constantemente direcionada a subempregos, aos quais se submete por medo do desemprego, essa mulher é traduzida e verificada em diferentes mulheres do "mundo real" que adentram e passam a fazer parte da narrativa enquanto personagens. Devidamente descritas (breve mas não superficialmente), acabam por delinear uma criatura maior e coletiva, personificada pela narradora repórter que "incorpora" a "mulher à procura de um emprego" e que realiza a mediação entre o mundo do leitor e o mundo das personagens apresentado na narrativa.

Essa concentração de características, reunidas e representadas na figura da narradora-personagem, ocasiona identificação e reflexo, ao mesmo tempo em que, num movimento dialeticamente oposto, desencadeia distanciamento crítico. Aliás, a narradora-personagem poderia ser entendida como uma "personagem elaborada com fragmentos de vários modelos vivos, sem predominância sensível de uns sobre outros, resultando numa personalidade nova" (CANDIDO, 2014, p. 73), se retomássemos as categorias enumeradas por Candido. O que poderia dar errado com relação à "encarnação" do papel, pois a aventura da repórter (que, em princípio, não pertence à categoria a qual se reporta, mas se coloca em situação) poderia ser reduzida à estereotipia no tratamento das personagens ou à arrogância de quem conduz a narrativa, o que certamente comprometeria a reportagem. Mas o risco e a possível "densidade obscura" por parte de quem escreve acaba reforçando e fortalecendo a tessitura de uma paradoxal personagem sem voz que se destaca e ganha força pela sua ausência de poder. Essa personagem subempregada coletiva, porque fruto de uma colagem de caracteres que se repetem e se somam ao longo da narrativa, pode ser percebida como heroica e protagonista em contraponto, na reportagem, ao personagem-antagonista patrão. E isso é alcançado principalmente pela condensação de todas as figuras e características das diferentes mulheres trabalhadoras abordadas em uma única máscara, vestida e incorporada pela própria narradora-personagem que mergulha na peregrinação a que são condicionadas milhares de trabalhadoras diariamente. A somatória de personagens tornadas invisíveis, além de reforçar a parte referencial da reportagem - que visa à denúncia do tratamento desferido às pessoas que buscam sua sobrevivência em diferentes empregos ou subempregos -, confirma também a ideia de singularização do universal, apontada por Sartre, agora na dimensão jornalística (por se tratar de texto do gênero, ainda que com lampejos literários). Por intermédio de personagens reais transformadas em fictícias e trazidas para a narrativa da saga anti-heroica da narradorapersonagem-repórter (saga que se confunde com a das demais personagens pelo artifício da máscara), o leitor obtém acesso à realidade sistêmica em que está inserido sem ser conduzido estritamente pelo discurso referencial ou histórico, comumente privilegiados em textos do campo jornalístico. É pela parcela de ficção presente na reportagem que o leitor trava contato com o factual singularmente universalizado -, quiçá de maneira mais lógica e orgânica.

\section{Referências}

CANDIDO, Antonio. A literatura e a formação do homem. In: Ciência e Cultura, São Paulo, v. 24, n. 9, 1972.

CANDIDO, Antonio. O direito à literatura. In: Vários escritos. [Edição revista e ampliada]. São Paulo: Duas Cidades, 1995.

CANDIDO, Antonio (Org.). A personagem de ficção. São Paulo: Perspectiva, 2014.

ECO, Umberto. Sobre algumas funções da literatura. In: Sobre a literatura. Rio de Janeiro: Record, 2003.

MANGUEL, Alberto. Uma história da leitura. São Paulo: Companhia das Letras, 1997.

SARTRE, Jean-Paul. O que é a subjetividade? Rio de Janeiro: Nova Fronteira, 2015.

SODRÉ, Muniz; FERRARI, Maria Helena. Técnica de reportagem: notas sobre a narrativa jornalística. São Paulo: Summus, 1986

TODOROV, Tzvetan. A literatura em perigo. Rio de Janeiro: DIFEL, 2012

Recebido: $13 / 12 / 16$

Aprovado: 22/02/17

Contato: meihuasoares@gmail.com 